\title{
Effects of economic growth in the behavior of sticky costs of companies belonging to BRICS countries
}

\author{
Efectos del crecimiento económico en el comportamiento de los costos \\ pegajosos de las empresas pertenecientes a los países BRICS \\ Vinícius Costa da Silva Zonatto ${ }^{1 *}$, Cristian Baú Dal Magro ${ }^{1,2}$, \\ Camila Freitas Sant ${ }^{\prime}$ Ana ${ }^{1}$, Daniel Fernando Padilha ${ }^{1}$ \\ ${ }^{1}$ Universidade Regional de Blumenau, Brazil \\ ${ }^{2}$ Universidade Comunitaria da Região de Chapecó, Brazil
}

Received 23 May 2016; accepted 24 April 2017

Available online 17 September 2018

\begin{abstract}
Costs tend to increase more when activities are still in the ascendant. The behavior of costs to business needs to be controlled and managed, so there is the maintenance of competitiveness organizational capacity, whether in times of economic crisis or during boom times. Despite that, few studies are dedicated to evaluate the effects of economic growth on the behavior of costs. This study investigates the effects of economic growth in the behavior of sticky costs of companies belonging to the BRICS countries, noting periods of prosperity and recession. The research population comprises companies listed on the stock exchange of Brazil, Russia, China and South Africa. The survey sample comprised 66 companies in Brazil, 19 in Russia, 150 in China and 25 in South Africa, totaling 260 companies. The study period was from 2004 to 2013, in which criteria have been established to delineate the effects of economic growth in the behavior of the costs of companies in periods of economic growth and recession. The results indicate that the costs have asymmetric behaviors in certain accounts and also vary in relation to different economic environments related companies located in the BRICS countries. This evidence support the conclusion that the asymmetric costs behavior occurs differently between BRICS, indicating that the costs

*Corresponding author.

E-mail address: viniciuszonatto@gmail.com (V.C. Silva Zonatto)

Peer Review under the responsibility of Universidad Nacional Autónoma de México.

http://dx.doi.org/10.22201/fca.24488410e.2018.1110

0186- 1042/C 2018 Universidad Nacional Autónoma de México, Facultad de Contaduría y Administración. This is an open access article under the CC BY-NC-SA (https://creativecommons.org/licenses/by-nc-sa/4.0/)
\end{abstract}


of asymmetry level can vary systematically between the cost accounts, business, different industries and countries. It was noted that in economic prosperity period the cost increase is less than in a decrease in response to changes in demand in the same proportion. In the period of economic recession the decrease of costs is less than its increase.

JEL Classification: M41, D24, M10.

Keywords: Sticky costs; Economic growth; BRICS countries.

\section{Resumen}

Los costos tienden a aumentar más cuando las actividades aumentan. El comportamiento de los costos en las empresas debe ser controlado y administrado, para el mantenimiento de la competitividad y capacidad organizativas, ya sea en tiempos de crisis económica o durante los tiempos de auge. No obstante, su importancia, pocos estudios se dedican a evaluar los efectos del crecimiento económico sobre el comportamiento de los costos. Este estudio investiga los efectos del crecimiento económico en el comportamiento de los costos pegajosos de las empresas pertenecientes a los países BRICS, observando períodos de prosperidad y recesión. La población investigada comprende empresas cotizadas en la bolsa de valores de Brasil, Rusia, China y Sudáfrica. La muestra incluyó 66 empresas de Brasil, 19 de Rusia, 150 de China y 25 de Sudáfrica, haciendo un total de 260 empresas. El período de estudio fue de 2004 a 2013, en el que establecieron criterios para delimitar los efectos del crecimiento económico en el comportamiento de los costos de las empresas en períodos de crecimiento económico y de recesión. Los resultados indican que los costos tienen comportamientos asimétricos en ciertas cuentas y también varían en relación con los diferentes entornos económicos relacionados con las empresas ubicadas en los países BRICS. Esta evidencia apoya la conclusión de que el comportamiento asimétrico de los costos ocurre de manera diferente entre los BRICS, lo que indica que el nivel de asimetría de costos puede variar sistemáticamente entre las cuentas de costos, negocios, industrias y países. Se observó que en el período de prosperidad económica el aumento de los costos fue menor que en disminución, en respuesta a cambios en la demanda en la misma proporción. En el período de recesión económica la disminución de los costos es menor que su aumento.

Códigos JEL: M41, D24, M10.

Palabras clave: Costos pegajosos; Crecimiento económico; países de el BRICS.

\section{Introduction}

The increasing competition in the business sector and due to new requirements of customers and consumers, regarding the sophistication of products and services, led the organization to face new needs, to promote and develop practices that contribute to the reduction of costs without that results in decreased quality of products and services.

Denotes that the behavior of costs is a key issue in the context of managerial and cost accounting, the direct influence it has on the decision making of managers. The methods used by management accountants and financial analysts directly depend on the behavior of costs, such as the costing method $\mathrm{ABC}$, the cost estimate and analysis of the cost, volume and profit. Such technique assumes that there is a relation between the costs and organizational activities, so that they are based on the estimate that the costs are changed in accordance with the proportion of changes in activities. Thus, the increase or decrease in activity should provide a symmetrical response in costs, i.e., an increase or decrease to be treated (Ibrahim, 2015). 
Some empirical studies claim that the relation between costs and activities is not always linear. For Malcolm (1991) many indirect costs do not change significantly in proportion to the change of activities. Rayburn (1993) mentions that the counters have the premise that there is a linear relation between the costs and the change in the volume of activities, but economists suggest the opposite, that the relationship is not linear. In this perspective, Cooper and Kaplan (1998) report that the cost increase in response to increased activity is greater than its proportionate decrease in response to a decrease in activity, which involves the asymmetric behavior of costs, contradicting often traditional assumption of linear costs to activities.

The literature provides empirical evidence that the costs do not always react in a linear way, as suggested by the theory of traditional costs, and the seminal study by Anderson et al., (2003), which showed the sticky cost behavior, known as sticky costs. Such research made emerge new empirical evidence, under which proved the existence of asymmetry in costs, as the findings from studies by Subramaniam and Weidenmier (2003), Calleja et al., (2006), He et al., (2010) Porporato and Werbin (2012), Borgert and Richartz (2014), Balakrishnan et al., (2014), Ibrahim (2015) and Pamplona et al., (2016).

The results of these studies indicate that the costs increase more when the activities remain in the ascendancy, and point out that the costs increase more than grow in response equivalent activities. Therefore, these results suggest confirmation of sticky cost behavior and the premise established by the theory of traditional costs. Despite evidence to suggest the existence of sticky cost behavior, few studies seek to investigate the behavior of costs in an environment of prosperity and recession, theoretical gap that stimulates new studies.

There is evidence for internal and external variables that can influence the behavior of asymmetric costs. Accordingly, Anderson et al., (2003), Calleja et al., (2006) and Dierynck et $a l .$, (2012), show the influence of internal variables and the specific characteristics of companies, such as the structure of assets, number of employees, level of indebtedness, working capital, industry, size, profitability, asset return and equity.

They point out that macroeconomic characteristics, such as GDP growth, can affect the asymmetric behavior of costs (Anderson et al., 2003; Yükçü \& Özkaya, 2011; Porporato \& Werbin, 2012; Balakrishnan et al., 2014; Banker, Byzalov \& Plehn-Dujowich, 2014, Ibrahim, 2015). Balakrishnan, Labro and Soderstrom (2011), Yükçü and Özkaya (2011), Porporato and Werbin (2012), Banker, Byzalov and Plehn-Dujowich (2014) and Ibrahim (2015) show that favorable GDP growth conditions create positive expectations In managers and, recession conditions generate negative expectations in managers. So when managers are optimistic, they tend to keep resources down even with reductions in production volume, and with it come Sticky Costs.

Abu-Serdaneh (2014) inferred that GDP growth caused asymmetries of costs in Jordanian companies, and on the other hand, in periods of GDP decline, companies presented lower asymmetries in costs. Richartz (2016) identified the influence of GDP growth on the asymmetry of costs of Brazilian companies.

There is also evidence from studies related to the impact of external factors on the asymmetric behavior costs. In this case, Calleja et al., (2006), Chen et al., (2012), Richartz and Borgert (2014) highlight the different corporate governance systems and Ibrahim (2015) the impact of economic growth on cost stickiness. The study by Ibrahim (2015) in companies of Egypt constituted one of the few to evaluate the effects of economic growth on the asymmetric behavior of costs, given periods of economic prosperity compared to periods of economic crisis. 
There is a lack of studies that seek to investigate the behavior of costs in an environment of prosperity and recession. The previous studies, who observed macroeconomic variables, focus on the research of economic growth in a secondary manner or limited to observe the influence of macroeconomic factors on the behavior of costs in a single country.

In this context, the premise to fill the gap in this theoretical research identified in the literature search with this study to answer the following research question: What are the effects of economic growth in the behavior of sticky costs of companies belonging to the BRICS countries in times of prosperity and economic recession? To answer this research question, has the objective to identify the effects of economic growth in the behavior of sticky costs of companies belonging to the BRICS countries, noting periods of prosperity and recession.

The justification for this study parts from the premise that economic growth and cost stickiness are correlated. Zuijlen (2012) showed in their study the confirmation of the hypothesis that companies have more cost stickiness in economic period of prosperity than in times of crisis. Dierynck et al., (2012) documented that during periods of low economic growth, managers reduced the search for resources when demand increases and have more slack resources when demand decreases, influencing cost stickiness. This context justifies the period analyzed in this study, pre-crisis from 2006 to 2008 and post-crisis between 2009 and 2011.

Research on the subject is relevant given that the Management Accounting Section Midyear Meeting has given prominence to the theme of stick cost (Balakrishnan et al., 2014; Frezatti et al., 2015). In addition, the study is justified because of expanding the existing literature from a cross-countries analysis in developing countries, considering that earlier studies found outside influences on the behavior of costs in a single country, as in the study Richartz and Borgert (2014) and Ibrahim (2015).

The analysis includes aspects related companies belonging to the BRICS countries (Brazil, Russia, India, South Africa and China) under which it is considered relevant, given that Frezatti et al., (2015) point out that the research of management accounting in the context of sticky costs are expected to grow in coming years.

Balakrishnan et al., (2014), Chen, Lu and Sougiannis (2012), Banker and Byzalov (2014), Banker et al., (2014), Richartz (2016), tested the hypothesis that cost asymmetry is a phenomenon that results from the deliberate behavior of managers, and in addition, Chen et al., (2012) mention that cost behavior studies should assess the interference of corporate governance mechanisms. In this way, developing countries have different and sometimes less effective corporate governance mechanisms, which also have an impact on the behavior of managers. In this premise, it is necessary to study the asymmetric behavior of costs in a group of countries that make up a developing economic group.

In addition, Yükçü and Özkaya (2011) point out that there is little research applied to the issue of cost behavior, especially in countries with emerging economies. However, for the authors, these countries deserve research because they differ from developed countries in many respects - such as the volatility of macroeconomic conditions, regulations, and labor market characteristics - that affect the behavior of costs through different dynamics. In this sense, it has been that Brazil, as a developing country and slightly internationalized, as well as other members of the BRICS, making itself an interesting topic for the international level.

Finally, it is justified because of the financial crisis in the United States in 2008 and later the crisis in Europe, heated the debate on the role of cost accounting (Power, 2009), emphasizing the opportunity to researchers from developing countries they have to pursue that discussion, 
showing how the global economic recession may affect different countries with different management tools, especially regarding to cost control (Frezatti et al., 2015).

\section{Theoretical hypotheses and research}

\section{Sticky costs}

In an attempt to prospect largest number of customers, commercial and business centers are constantly expanding to promote niche markets. With new looks trends, the consequence is portrayed through the significant increase in competitiveness. In this context, it reinforces the idea of companies seek improvements in the production and management processes to maintain competitiveness and innovation (Scharf et al., 2011).

Decision-making on organizational activities should be based on the prior knowledge about the behavior of costs. If it does not, the organization may suffer future problems, as in the case of insolvency (Garrison and Noreen, 2001). Consequently, managers can use the cost behavior analysis to manage them so that properly respond to changes in activity levels.

According to Anderson et al., (2003), managers use the cost behavior manipulation, given by the changes that perform to generate an increase in the volume of spending, thus following the increase in sales volume. However, some managers decide to keep costs rather than make adjustments that involve the reduction, due to the inverse relation, which would be the reduction of costs to accompany the reduction in sales volume, does not. Denotes that the option to keep the high costs, while there is a decrease in turnover, can be connected to the manager's personal interests, and thus result in costs agency.

Jensen and Meckling (2008) transcribed this fact, related to agency costs, in line with the decision of managers to maximize their own interests without considering the interests of shareholders, keeping unnecessary expenses that can contribute to the asymmetric cost behavior.

Reference is that optimism manager is perceived as impeller to acquire additional resources, under which Banker et al., (2014) point out that the existence of this factor assists in the management of the balance of the increase in sales, in order to minimize unused resources when sales register reduction. In this sense, it is clear that the costs of adaptation and management expectations allow lead to a systematic reversal in the direction of asymmetry, which ends up generating a new perspective on the structure of the asymmetric cost behavior, due to the form of management.

Thus, it denotes that cost stickiness occurs when there is a reduction in sales volume, while managers decide to keep idle resources, rather than adjust costs to lower sales volume (Anderson et al., 2003). In this context, the authors emphasize that specific properties comprise asymmetric costs as well as any change in sales revenue which may reflect short-term market conditions, or long-term changes in demand for products and services. Furthermore, it has asymmetric elasticity against revenue variations mentioned by Medeiros et al., (2005), which causes increase in the cost of greater intensity than the increased revenue.

Porporato and Werbin (2012) characterize the behavior given by the sticky costs approach, considering the theoretical aspects based on management accounting, as "sticky" costs, referring directly to asymmetric costs that occur due to changes in the level of activity. Thus, from the relation between activities and costs, the literature distinguishes two types of costs being fixed costs and variable costs. The first can be considered independent activity level, and the second can be changed linearly and proportionately to changes in the activity level (Calleja et al., 2006). 
Balakrishnan and Gruca (2008) presented a model of asymmetric costs that is characterized by considering the cost incurred in the previous period, has the ability to affect the costs incurred in the current period. So that the level of activity recorded in the current period and the previous period also generates effects on the costs incurred in the current period. Thus, it is emphasized that this model considers a form of strategic behavior, due to adjustments in the activities from the decision making of managers.

Empirical evidence provide subsidy over the asymmetric cost behavior. Noreen and Soderstrom (1994) sought to determine if indirect costs are proportional to the company's activity. Using a sample of hospitals located data in the state of Washington, the results indicate that the costs are not proportional to changes in activity. Noreen and Soderstrom (1997) examined the behavior of costs in time series, under which concluded that the systems that depend on the traditional costing assumption, as the $\mathrm{ABC}$ system costs, impact on changes in the activities costs, but the evidence does not it was striking to observe the asymmetry costs.

Anderson et al., (2003) investigated the asymmetry in costs, based on the analysis of increased costs and decreased or increased activity level, providing identify if costs are sticky. For this, we used a sample of 7,629 companies, observing the behavior of costs through traditional model during the period of 20 years. The research findings indicate that the costs behave in proportion to activity changes, due to the asymmetric cost model originated from the adjustment of decisions on costs made by managers engaged in the activity.

In order to test the asymmetric elasticity of cost of 198 Brazilian companies in relation to revenue variations, based on the evidence of the companies located in the northern United States, the research developed by Medeiros et al., (2005), through panel data analysis, considering a period of 17 years, he found evidence that contradicts previous studies, so we realized that the asymmetry does not seem to diminish when observing a cross section period, implying that the model developed by Anderson et al., (2003) has applicability in Brazil to watch the sticky cost behavior.

Furthermore, Calleja et al., (2006) provide evidence for cost stickiness in a cross- countries study, considering a group of developed countries (USA, UK, France and Germany) from 1988 to 2004. The evidence indicates the existence of asymmetry in the cost of companies of the four countries, and noted that the German and French companies, the costs are more fixed than in American and British companies.

Anderson and Lanen (2007) demonstrated the fragility as the asymmetric costs and also that the management behavior is connected to the hypothesis of asymmetric cost. However, they did not obtain results about the behavior of costs, faced with other models subject to management aspects, such as labor costs. Thus, it was deemed insufficient database and methods used to a conclusion about the managerial decision-making theory and cost management, generating concerns for future research.

Another examination was performed by Balakrishnan and Gruca (2008) in hospitals, which found the behavior of asymmetric costs in the short term, using the model proposed by Anderson et al., (2003). This involving data departmental cost, enabled to examine the viscosity of the costs, and that the changes are influenced by the environment.

Managers when faced with falling sales, tend to take some cost decisions. Thus, some managers prefer to wait for recovery of the market, lower cost and other ready manner, in order to maintain the commercial stability. The study Yasukata (2011) found that the viscosity of the costs is in accordance with the decisions of managers. Therefore, testing empirically whether 
future sales accuracies have an impact on costs, the author pointed out how true the hypothesis that viscosity costs is a result of the decision making of managers.

Using the sample of 669 public companies from nine Latin American, Costa, Marques, Santos and Lima (2013) report that when an increase in revenue occurs, the cost variation is greater than a reduction On the same proportion. In addition, they concluded that selling expenses are asymmetric in comparison with changes in net sales, in which the authors support the hypothesis that outdated in periods, there is a possible reversal asymmetry. However, observing periods over the 12 months, and considering more than one year, they consisted that the asymmetry does not diminish, not being influenced by outdated periods.

Through a survey study considering 136 companies listed on BM\&FBovespa over 10 years Richartz et al., (2014) identified is a link between spending on labor and fixed costs. Conclusively report that higher spending on labor do not influence the asymmetry of the total costs accrued by organizations. In addition, found that the level of restraint, given the fixed cost divided by total costs, does not influence the level of asymmetry of the Brazilian business costs, on the grounds that the companies with the lowest proportion in costs in relation to labor in total cost, have greater variability in costs.

In the study developed by Balakrishnan et al., (2014), it was found that both the fixed cost structure and the structure of variable costs, end up generating asymmetric costs. According to the authors, the controls included in the analysis of the asymmetric behavior of costs are reflective of management actions. Finally, studies have been done with developing countries, focusing on Latin America. Marques, Santos, Lima and Souza Costa (2014) analyzed whether the costs of publicly held companies in Latin American countries vary asymmetrically in terms of revenue, with a sample of 669 publicly held companies from nine countries (which includes Brazil) for the period 1995 to 2012. The results of this research suggest that the behavior of Sales, General and Administrative Expenses is asymmetrical in relation to changes in sales revenue.

Pamplona et al., (2016) investigated the cost behavior of the 50 largest listed companies in Brazil, Chile and Mexico listed on the BM \& FBOVESPA, the Santiago Stock Exchange and the Mexican Stock Exchange, with emphasis on the analysis of the Sticky Costs. With a longitudinal analysis (2002 to 2013) supported by the technique of panel data analysis, the authors present that the behavior of costs in the largest publicly traded companies in Brazil, Chile and Mexico are asymmetric and the increase in costs by increasing the Net sales revenue is higher when compared to the reduction in costs due to a proportional reduction in net sales.

As can be seen from the review of previous studies developed under the theme, revisited literature presents strong evidence of sticky costs in different groups of countries. The literature attributes this behavior to different reasons, considering the optimism and pessimism of managers in relation to demand, earnings management to the cost system adopted by companies, government legislation, among other factors. So, considering that the previously mentioned behaviors can exist in any business environment, the study raises the hypothesis that the costs in the business environment of the BRICS countries, can respond asymmetrically, thus creating the general hypothesis of this research (H1):

$\mathrm{H} 1$ - Costs respond asymmetrically to a change in equivalent sales revenue in the companies belonging to the BRICS countries. 


\section{Asymmetry costs and financial crisis}

Despite evidence suggesting such behavior in different business environments, little is known about the asymmetry of costs against a backdrop of prosperity and recession, theoretical gap that stimulates new studies. In this regard, economists believe that the global financial crisis that began in late 2008, was one of the worst since the Great Depression occurred in 1930, when world financial markets experienced historic collapse in its financial ratios (Ibrahim, 2015).

Therefore, moments of crisis or economic prosperity can be desirable for the development of further studies on the behavior of costs. The literature provides evidence that cost stickiness can increase during economic prosperity. Anderson et al., (2003) explain that during the economic prosperity there is a probability that demand will grow in a linear fashion and continues. This fact induces managers to delay a cost-cutting decision, incurring the asymmetry, and indicating a positive correlation between high rates of PIB and cost stickiness.

Zuijlen (2012) hypothesizes that companies in crisis periods cease to provide cost stickiness, and Ibrahim (2015) mention that the costs have increased inequality during the period of prosperity since the ascendancy of economic growth, in line the presentation of favorable macroeconomic indicators, encourage managers to make investments, and leads to a permanent context of increased demand and a temporary decline. Thus, these managers ultimately increases resources in this context of increased demand and delays the decline of such resources on a possible decline. Faced with such evidence, it becomes possible to establish the second hypothesis of the research (H2):

$\mathrm{H} 2$ - In times of economic prosperity, the cost increase is higher than in a decrease in response to $1 \%$ change in demand, ie they have asymmetry in costs.

They also found evidence indicating the minimization of cost stickiness in times of crisis or weak economic growth. Dierynck et al. (2012) suggested that weak economic growth prospects leads managers to postpone funding resources when demand increases, and turns off the feature when demand decreases. Such intervention can result in reduced cost stickiness or in his absence in times of recession. Zuijlen (2012) mentions that the asymmetry of costs is lower in times of crisis, due to cuts in spending and management support for the maintenance of slack resources. In addition, there is evidence that organizations avoids entering into long-term contracts during periods of economic crisis, minimizing cost stickiness.

Ibrahim (2015) mentions that the increased costs in response to increased demand, may be lower than that in response cost reduction to decreased demand in periods of economic recession. In this case, the costs have no asymmetric behavior because the frustrating economic scenario cause pessimism on the part of the managers regarding the possibility of increased demand.

In this case, the costs have asymmetric behavior because the frustrating economic scenario because pessimism by managers as to increased demand. Balakrishnan et al., (2014) argue that when managers are facing a pessimistic economic scenario, the costs tend to not behave asymmetrically. The authors provide evidence of this absence asymmetry in 3 of the 25 industries observed in their study. Therefore, this study provides that the activities of the managers during periods of economic recession can lead to the absence of sticky cost behavior, incurring the establishment of the third research hypothesis (H3):

H3 - During periods of economic recession and financial crisis, the decrease in costs is larger than its increase in response to $1 \%$ change in demand, ie they do not have asymmetry in costs.

Ibrahim (2015) establish a premise that the behavior of costs can follow different paths, 
since they are covered prosperity scenarios and economic recession. In this sense, if demand increases by $1 \%$, the cost will increase to a greater extent in the economic prosperity period, than in the recession period. Thus, managers were considering permanent optimistic scenario and a temporary pessimistic one. Such evidence allows the preparation of the fourth hypothesis of this research (H4):

$\mathrm{H} 4$ - If demand increases by $1 \%$, the cost will increase in greater proportion in the economic prosperity period than during the economic recession.

On the other hand, if the costs fall in greater proportion in the period of economic recession, than in the period of economic prosperity, managers are considering a permanent negative environment and temporary positive (Ibrahim, 2015). Given the above, it was determined the fifth hypothesis to be tested in this study (H5):

H5 - If demand decreases by $1 \%$, the costs will decrease in greater proportion in the economic recession period than during the economic prosperity.

Given the theoretical and empirical foundations that support the hypothesis to be tested in this study, then presents the methodological procedures employed for the study.

\section{Methodological procedures}

To identify the effect of economic growth on the behavior of sticky costs of companies belonging to the BRICS countries, took place a research through document analysis and quantitative analysis of data.

The research population comprised all companies listed on the stock exchange of Brazil (BM\&FBOVESPA), Russia (Micex Stock Exchange - MICEX), China (Shanghai Stock Exchange - SSE) and South Africa (Johannesburg Stock Exchange - JSX). As the sample for the survey, companies were excluded classified as financial and insurance, as well as those that did not contain the information needed to analyze the data. In addition, India companies were excluded, since did not release all necessary information during the timeline studied. Thus, the sample used in this research included 66 companies from Brazil, 19 from Russia, 150 in China and 25 in South Africa, totaling 260 companies.

Data collection was performed in the Thomson ${ }^{\circledR}$, considering the information published annually by the financial statements of the companies surveyed during the period 2004 to 2013. The timeline was determined considering the study Richartz and Borgert (2014), in highlighting the consideration of a longitudinal period appropriate to the cost behavior research, showing accurately the variations and trends, strengthening the reliability of the results.

To examine the behavior of costs in relation to the economic aspects, was established economic prosperity period considering the five years preceding the 2008 financial crisis, ie the periods 2004 to 2008 . On the other hand, to evaluate the behavior of costs in the economic recession period were considered the five years after the onset of the financial crisis of 2008, ie 2009 to 2013.

A robustness test was performed to corroborate the assumptions of effects of economic growth in the behavior of sticky costs. To this end, it considered two different periods, from 2004 to 2008, where countries had the highest rates of PIB, which is the characteristic outline for economic prosperity. On the other hand, there are other two periods, between 2009-2013, in which countries had the lowest rates of PIB, which were characterized by recession.

The information collected grasped the net sales, cost of goods sold, selling expenses and 
administrative expenses. According to the study Richartz and Borgert (2014) financial expenses were not considered due to related to the capital structure of companies, under which the authors denote that verification of the efficiency of business operations should not be confused with forms of financing.

The model used for the evaluation of sticky costs has been developed based on the study of Anderson et al., (2003), who used the method of Ordinary Least Squares (OLS) for analysis by panel data regression, time series matching with use of cross-sectional data. Thus, there is the equation used to check on the econometric model:

$$
\begin{gathered}
\log \left[\frac{S G \& A_{t}}{S G \& A_{t-1}}\right]=\beta_{0}+\beta_{1} \log \left[\frac{\text { Revenue }_{i, t}}{\text { Revenue }_{i, t-1}}\right]+\beta_{2} \text { Dummy }_{i, t} * \log \left[\frac{\text { Revenue }_{i, t}}{\text { Revenue }_{i, t-1}}\right]+\varepsilon_{i, t} \\
\log \left[\frac{\text { COGS }_{t}}{\operatorname{COGS}_{t-1}}\right]=\beta_{0}+\beta_{1} \log \left[\frac{\text { Revenue }_{i, t}}{\text { Revenue }_{i, t-1}}\right]+\beta_{2} \text { Dummy }_{i, t} * \log \left[\frac{\text { Revenue }_{i, t}}{\text { Revenue }_{i, t-1}}\right]+\varepsilon_{i, t} \\
\log \left[\frac{\text { OC }_{t}}{\text { OC }_{t-1}}\right]=\beta_{0}+\beta_{1} \log \left[\frac{\text { Revenue }_{i, t}}{\text { Revenue }_{i, t-1}}\right]+\beta_{2} \text { Dummy }_{i, t} * \log \left[\frac{\text { Revenue }_{i, t}}{\text { Revenue }_{i, t-1}}\right]+\varepsilon_{i, t}
\end{gathered}
$$

The models were used to assess the reaction of the costs to variability in selling, general and administrative (SG\&A) costs of goods sold (COGS) and operational costs (OC), in relation to the change in net sales revenue (Revenue), as well as to identify the variations increase or decrease in revenues in each period. The method used was designed to assess the level of sticky costs, even taking the logarithm used to demystify the diversity of companies, as performance and size, in order to decrease the cross heterocedasticity data and improve the comparison of the variables (Anderson et al., 2003).

Still, there is a dummy variable was assigned, considering that it takes the value of 1 when i company's revenue in period t is less than the revenue from period t- 1 and 0 if otherwise. The coefficient $\beta 1$ determines the percentage reduction in costs compared to the $1 \%$ increase in revenue. However, when revenue decreases the sum of the coefficients $(\beta 1+\beta 2)$ shows the percentage reduction in cost compared to $1 \%$ reduction in revenue suffered. Given the behavior, it is argued that the costs will present asymmetry if their variation in relation to the increase in revenue is greater than the variation in relation to the reduction of revenue (Anderson et al. 2003; Ibrahim, 2015).

So, for data analysis were used statistical techniques of descriptive data analysis and data regression analysis panel, developed by means of SPSS $®$ Statistics and STATA® software.

\section{Description and analysis of results}

\section{Descriptive statistics}

It appears in Table 1 that the highest average selling, general and administrative focuses on companies from Russia, and the lowest average on China's companies. In relation to costs of goods sold, the highest average focuses on companies from Russia and the lowest average for 
Table 1 presents the descriptive statistics of the variables used in the research.

Table 1

Descriptive statistics of the variables used

\begin{tabular}{lcccccccc}
\hline Countries & Variables & Media & $\begin{array}{c}\text { Expenses / } \\
\text { Revenue }\end{array}$ & SD & Minimum & Maximum & Observation & N. \\
\hline \multirow{5}{*}{ South Africa } & SG\&A & 357.77 & $11.94 \%$ & 322.63 & 4.96 & $2,479.08$ & 250 & 25 \\
& OC & $2,684.88$ & $89.57 \%$ & $3,257.05$ & 48.38 & $16,640.94$ & 250 & 25 \\
& Revenue & $2,997.38$ & & $2,694.69$ & 54.57 & $17,477.90$ & 250 & 25 \\
\hline \multirow{5}{*}{ Russia } & SG\&A & 762.02 & $14.31 \%$ & 907.77 & 2.47 & $4,782.78$ & 190 & 19 \\
& COGS & $2,973.38$ & $55.83 \%$ & $2,774.95$ & 128.25 & $14,056.4$ & 190 & 19 \\
& OC & $4,523.26$ & $84.93 \%$ & $4,825.30$ & 207.41 & $29,596.94$ & 190 & 19 \\
& Revenue & $5,325.87$ & & $5,844.61$ & 218.62 & $35,001.39$ & 190 & 19 \\
\hline \multirow{5}{*}{ Brazil } & SG\&A & 302.01 & $14.53 \%$ & 546.12 & 3.86 & $4,630.77$ & 660 & 66 \\
& COGS & $1,258.53$ & $60.56 \%$ & $1,120.81$ & 0.91 & $14,795.26$ & 660 & 66 \\
& OC & $1,766.83$ & $85.01 \%$ & $2,463.12$ & 18.13 & $16,763.04$ & 660 & 66 \\
\multirow{5}{*}{ China } & Revenue & $2,078.26$ & & $1,818.99$ & 4.68 & $17,786.66$ & 660 & 66 \\
& SG\&A & 182.88 & $8.04 \%$ & 188.57 & 1.01 & $3,983.05$ & 1500 & 150 \\
& COGS & $1,769.34$ & $77.79 \%$ & $1,867.71$ & 2.52 & $27,631.89$ & 1500 & 150 \\
& OC & $2,112.97$ & $92.90 \%$ & $2,158.50$ & 15.08 & $28,358.42$ & 1500 & 150 \\
\hline
\end{tabular}

Amounts in millions / billions of dollars (US).

Source: Research data.

companies in Brazil. The same applies to operating costs. Regarding the revenues from sales, the findings indicate that companies located in Russia had the highest average revenues from sales, on the other hand the smallest occurred in companies in Brazil.

In general, it is observed that China's companies have the lowest percentage of selling, general and administrative expenses in relation to sales revenues. On the other hand, companies in Russia have the lowest percentage of cost of goods sold and operating costs in relation to sales revenues. Therefore, it is possible to infer that companies from Russia are more competitive compared to other companies analyzed, since they have higher revenues and lower production costs (COGS and OC).

Such conditions give opportunity to these companies work better prices for their products and determine greater investment to improve productivity and product quality. Figure 1 shows an overview of the descriptive analysis of the behavior of Selling, General and Administrative (SG\&A) of the Goods Sold Costs (COGS) and operational costs (OC) of companies that make up the survey sample, over period 2004 to 2013 for each country.

As shown in Figure 1, a downward trend can be seen in costs in the first five years and an increasing trend in the following years, returning to decrease in the last three years investigated in the survey. Thus, it can be inferred that during prosperous economic period all costs to cover the revenue was lower than in a crisis period.

It is observed that the behavior of selling, general and administrative, costs of goods sold and operating costs in South Africa and Brazil are similar, particularly between 2007 and 2009 that show an increasing trend for covers revenue. In contrast, in the periods 2008 and 2013 show a significant drop. Selling expenses, general and administrative costs of goods sold and operating costs in both countries are consistent variability, but different from that in China and Russia.

China presents a significant drop in 2009 and 2012 and a significant increase in 2010. These indications show that there is an asymmetry trend in costs of companies analyzed in 


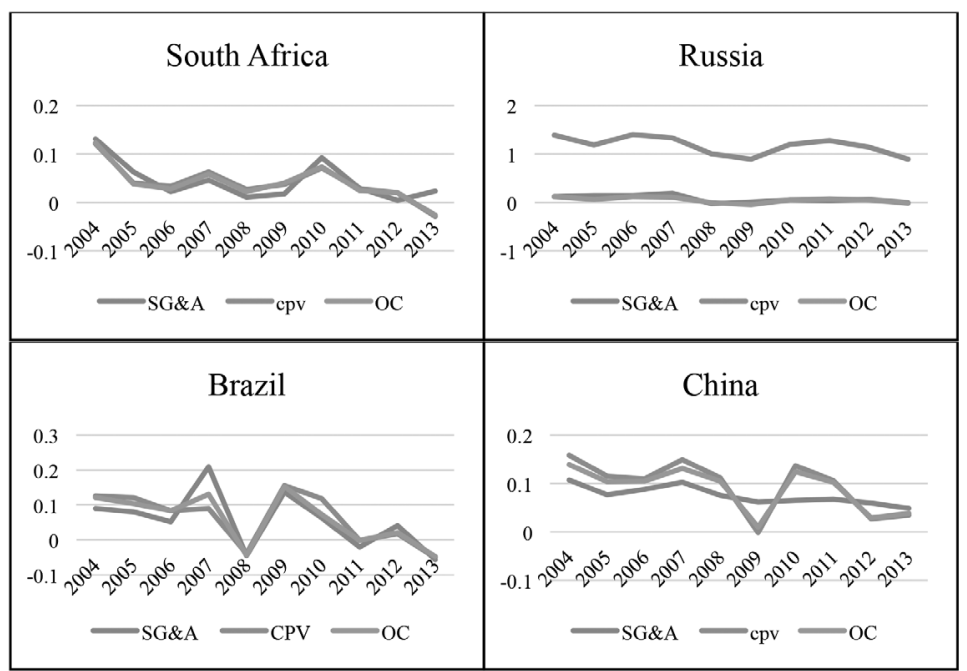

Figure 1. Evolution of the cost behavior change in the period 2004/2013 in the countries analyzed Source: Research data.

this country, because as noted in Figure 1, the trend of these costs is reduction and increased to cover the revenues. Russia showed up with a downward trend in costs over the period analyzed, suggesting that companies of this country did not have asymmetric behavior, as the chart shows little fluctuation in costs compared with the other countries analyzed in the study.

In general, it is observed that in China there is a greater variation in the behavior of cost of goods sold and operating expenses, and greater uniformity in the behavior of selling, general and administrative, which shows that the behavior of costs in this country should be seen in a different way from that observed in South Africa, Brazil and Russia.

In Russia, the results point to greater variability only related to costs of goods sold, evidence to confirm the behavior of the observation of the related costs to cost of goods sold, unlike highlighted findings in Brazil and South Africa, where it is must observe the variability of selling, general and administrative, costs of goods sold and operating costs.

\section{Cost behavior in period analyzed}

Table 2 shows the test results of the general model, which features the asymmetric behavior of costs in companies belonging to the BRICS countries, without taking into account the effects of economic growth.

Table 2 summarizes the results obtained by regression analysis the three models under study (SG\&A; COGS; OC) for companies in the four countries belonging to the BRICS. Thus, it is observed that in South Africa the adjusted value of the determination coefficient (adjusted $\mathrm{R}^{2}$ ) was 15.55 , which indicates that the model explains $15.55 \%$ of the variation in overhead, selling and administrative (SG\&A), determining that $84.45 \%$ of the variation found can be explained by other factors. The SG\&A expenses consist of various components of costs, such as marketing costs, rent, administrative buildings insurance and taxes related to the sale of products. Thus, the change in any of these components tends to move directly these costs. 
Table 2

Asymmetrical Cost behavior

\begin{tabular}{|c|c|c|c|c|c|c|c|c|}
\hline \multirow{2}{*}{ Country } & \multirow{2}{*}{ Period } & \multirow{2}{*}{ Model } & \multicolumn{2}{|c|}{ Increase } & \multicolumn{2}{|c|}{ Decrease } & \multirow{2}{*}{ Obs. } & \multirow{2}{*}{$\mathrm{R}^{2}$} \\
\hline & & & scenario & $\beta_{1}$ & scenario & $\beta_{1+} \beta_{2}$ & & \\
\hline \multirow[t]{3}{*}{ South Africa } & $2004 / 2013$ & SG\&A & $1 \%$ & $0.83 *$ & $1 \%$ & & 250 & $15.55 *$ \\
\hline & & COGS & $1 \%$ & $1.02 *$ & $1 \%$ & & 250 & $75.62 *$ \\
\hline & & $\mathrm{OC}$ & $1 \%$ & $0.99 *$ & $1 \%$ & $0.77 *$ & 250 & $83.70 *$ \\
\hline \multirow[t]{3}{*}{ Brazil } & $2004 / 2013$ & SG\&A & $1 \%$ & $0.94 *$ & $1 \%$ & $0.63 *$ & 660 & $34.75 *$ \\
\hline & & COGS & $1 \%$ & $1.10^{*}$ & $1 \%$ & $0.82 *$ & 660 & $49.54 *$ \\
\hline & & $\mathrm{OC}$ & $1 \%$ & $1.02 *$ & $1 \%$ & $0.74 *$ & 660 & $87.47 *$ \\
\hline \multirow[t]{3}{*}{ China } & $2004 / 2013$ & SG\&A & $1 \%$ & $0.61 *$ & $1 \%$ & $0.07 *$ & 1500 & $12.38 *$ \\
\hline & & COGS & $1 \%$ & $1.04 *$ & $1 \%$ & & 1500 & $77.52 *$ \\
\hline & & $\mathrm{OC}$ & $1 \%$ & $0.96^{*}$ & $1 \%$ & $0.83 *$ & 1500 & $88.53 *$ \\
\hline \multirow[t]{3}{*}{ Russia } & $2004 / 2013$ & SG\&A & $1 \%$ & $0.65^{*}$ & $1 \%$ & & 190 & $17.52 *$ \\
\hline & & COGS & $1 \%$ & $1.87^{*}$ & $1 \%$ & $2.68 *$ & 190 & $74.18 *$ \\
\hline & & $\mathrm{OC}$ & $1 \%$ & $0.78 *$ & $1 \%$ & & 190 & $73.24 *$ \\
\hline
\end{tabular}

* Significance at $5 \%$

Source: Research data.

Regarding main model coefficients, the coefficient $\beta 1(0.38)$ is positive and statistically significant, which indicates that when sales increase by $1 \%$, SG\&A increase by $0.38 \%$. However, the reduction of the sales cost behavior can not be explained, since the $\beta 2$ coefficient was not statistically significant. This result suggests rejecting the first hypothesis $(\mathrm{H} 1)$, in which costs this market do not respond asymmetrically changes in sales revenue.

Regarding the COGS, the model explains $75.62 \%$ of the variation. The $\beta$ coefficient (1) (1.02) is positive and statistically significant, indicating that when sales increase by $1 \%$, the cost of goods sold increased by $1.02 \%$. Regarding the reduction in sales, the behavior of cost of goods sold can not be explained by the fact that the $\beta \_2$ coefficient was not statistically significant, rejecting the hypothesis 1 of the research.

Regarding the operating costs (OC) model explains $83.70 \%$ of its variation. The $\beta \_1$ and $\beta_{-}$(2) coefficients are both statistically significant, and the sum of the two coefficients is 0.77 . Therefore, operating costs increases by $0.99 \%$ when sales increases by $1 \%$ and reduces only $0.77 \%$, when sales decrease by an equivalent amount, which indicates that the behavior of operating costs (OC) is sticky, consistent with the acceptance of the hypothesis 1 to South Africa. The results provide evidence that the economic situation affects the nature and magnitude of the asymmetric behavior for operating costs (OC), but not for the cost of sales, general and administrative (SG\&A) and the cost of goods sold (COGS) in this country.

In Brazil, it was verified asymmetric cost and sticky behavior for the three investigated models (SG\&A), (COGS) and (OC), which suggests the acceptance of the first hypothesis (H1). Although the results are consistent for the three models, there is some variability in the sticky costs and asymmetric, in which the costs related to SG\&A are explained in $34.75 \%$ by the model. Such costs increases by $0.94 \%$ when sales increases by $1 \%$, and reduces only $0.63 \%$ when sales decrease in equivalent amount, indicating asymmetric and sticky behavior.

The variation in cost of goods sold is explained in $49.54 \%$ by the model, and when sales increase by $1 \%$, the cost of goods sold (COGS) tend to increase by $1.10 \%$. On the other hand, when sales decreases by $1 \%$, the COGS tends to reduce in $0.82 \%$. In turn, the variation of the operating costs (OC) is explained in $87.47 \%$ by the model. In this case, the results indicate that increased sales by $1 \%$ leads to an increase in (OC) by $1.02 \%$, and the reduction in sales by $1 \%$ 
causes a decrease in (OC) in $0.74 \%$. So for all models tested the hypothesis 1 is accepted in Brazil.

Overall, it was not observed a significant difference in cost stickiness and a higher proportion of sticky costs for a given model (SG\&A, COGS, OC). The results suggest that the asymmetry of costs is proportionally similar between the cost of sales, general and administrative, cost of goods sold and operating costs in Brazil.

In China it was observed that there is no asymmetry in the cost of goods sold (COGS), rejecting the first hypothesis of the research (H1) investigated from this model. On the other hand, to selling, general and administrative (SG\&A) and operating costs (OC), the results indicate asymmetric behavior of costs, allowing the acceptance of the hypothesis 1 for both models. The change in selling, general and administrative (SG\&A) is explained in 12.38\% by the model and operating costs are explained in $88.53 \%$ by the model, being consistent, since operating costs are strongly related to productive activity unlike the selling, general and administrative, which consists of activities that permeate production.

Given the above, selling, general and administrative increase by $0.61 \%$, when sales increased by $1 \%$ and reduces by $0.07 \%$ when sales decrease in equivalent amount. Regarding operating costs, it is observed that the increase in sales of $1 \%$ leads to an increase in costs by $0.96 \%$, and reduced sales by $1 \%$ causes a reduction in operating costs in $0.83 \%$. The result indicates that in both cases, the behavior of costs is sticky and asymmetrical, and for selling, general and administrative asymmetry is intensified, as the decrease in sales causes little impact on reducing these costs.

In Russia, the results found also indicate the existence of asymmetry of costs only in cost of goods sold, which is explained by the model in $74.18 \%$. Thus, for selling, general and administrative, and operational costs, reject the first research hypothesis (H1). For the cost of goods sold, the hypothesis 1 is accepted. Given the results found, it appears that increased sales by $1 \%$ causes an increase in cost of goods sold at $1.87 \%$ and the decrease in sales equivalent ratio causes a reduction in the cost of products sold in $2.68 \%$. The evidence that the decrease in cost of goods sold is greater than to rise to an equivalent change in sales, is with the assumption that costs are sticky and non-sticky, confirming findings in studies by Weiss (2010), Banker et al., (2014) and Ibrahim (2015).

In summary, the results found in this stage of the research confirm that the nature and magnitude of the asymmetric behavior of costs vary between cost accounts. In the case of South Africa, the operating cost was higher than their reduction to a change of $1 \%$ in sales. In Brazil, selling, administrative and general, the cost of goods sold and operating costs were higher than their decreases for a change of $1 \%$ in sales. In China, selling, administrative and general and operating costs were higher than their reduction to a change in $1 \%$ in sales, and for the cases presented costs characterized as sticky. On the other hand, Russia decrease in cost of goods sold was higher than the increase for a $1 \%$ change in sales, in which case characterized as non-sticky.

Given the above, one can infer that these results provide evidence confirming the expectations of Banker et al., (2014) and Ibrahim (2015), wherein the degree of asymmetry costs can vary systematically between the cost accounts, companies, industries and countries, including the possibility of sticky and non-sticky costs, as seen in companies analyzed BRICS countries. 


\section{Behavior of costs in periods of prosperity and economic recession}

Following is the model that aims to establish the effects of economic growth on the behavior of sticky costs in order to test the hypothesis H2, H3, H4 and H5. To ascertain the economic growth factor, the sample of companies in each country was divided into two weights. At first, we sought to evaluate the effects of a period of economic prosperity, established before the financial crisis of 2008. In the second, considered a period of economic recession, we proceeded to the analysis after the period of 2008. Such procedures are convergent those adopted in the study by Ibrahim (2015). A summary of results is presented in Table 3.

Table 3

Asymmetrical behavior of costs in periods of prosperity and recession

\begin{tabular}{|c|c|c|c|c|c|c|c|c|}
\hline \multirow{2}{*}{ Country } & \multirow{2}{*}{ Period } & \multirow{2}{*}{ Model } & \multicolumn{2}{|c|}{ Increase } & \multicolumn{2}{|c|}{ Decrease } & \multirow{2}{*}{ Obs. } & \multirow{2}{*}{$\mathrm{R}^{2}$} \\
\hline & & & Scenario & $\beta_{1}$ & Scenario & $\beta_{1+} \beta_{2}$ & & \\
\hline \multirow{6}{*}{ South Africa } & $2004 / 2008$ & SG\&A & $1 \%$ & $0.91 *$ & $1 \%$ & \multirow{4}{*}{$1.27 *$} & 125 & $14.80 *$ \\
\hline & Prosperity & COGS & $1 \%$ & $0.96^{*}$ & $1 \%$ & & 125 & $84.68 *$ \\
\hline & & $\mathrm{OC}$ & $1 \%$ & $0.96^{*}$ & $1 \%$ & & 125 & $92.84 *$ \\
\hline & $2009 / 2013$ & SG\&A & $1 \%$ & $0.74 *$ & $1 \%$ & & 125 & $16.76^{*}$ \\
\hline & Recession & COGS & $1 \%$ & $1.07 *$ & $1 \%$ & $0.61 *$ & 125 & $66.78 *$ \\
\hline & & $\mathrm{OC}$ & $1 \%$ & $1.04 *$ & $1 \%$ & $0.60 *$ & 125 & $74.54 *$ \\
\hline \multirow{6}{*}{ Brazil } & $2004 / 2008$ & SG\&A & $1 \%$ & $0.99 *$ & $1 \%$ & \multirow{6}{*}{$\begin{array}{l}0.59 * \\
0.80 * \\
0.71 *\end{array}$} & 330 & $28.76^{*}$ \\
\hline & Prosperity & COGS & $1 \%$ & $1.01 *$ & $1 \%$ & & 330 & $41.60 *$ \\
\hline & & OC & $1 \%$ & $1.03 *$ & $1 \%$ & & 330 & $92.63 *$ \\
\hline & $2009 / 2013$ & SG\&A & $1 \%$ & $0.81 *$ & $1 \%$ & & 330 & $50.25 *$ \\
\hline & Recession & COGS & $1 \%$ & $1.29 *$ & $1 \%$ & & 330 & $58.14 *$ \\
\hline & & $\mathrm{OC}$ & $1 \%$ & $1.03 *$ & $1 \%$ & & 330 & $82.67 *$ \\
\hline \multirow{6}{*}{ China } & $2004 / 2008$ & SG\&A & $1 \%$ & $0.70^{*}$ & $1 \%$ & \multirow{5}{*}{$\begin{array}{l}0.85^{*} \\
0.15^{*}\end{array}$} & 750 & $16.50 *$ \\
\hline & Prosperity & COGS & $1 \%$ & $1.02 *$ & $1 \%$ & & 750 & $67.22 *$ \\
\hline & & $\mathrm{OC}$ & $1 \%$ & $0.95 *$ & $1 \%$ & & 750 & $87.68 *$ \\
\hline & $2009 / 2013$ & SG\&A & $1 \%$ & $0.50 *$ & $1 \%$ & & 750 & $7.92 *$ \\
\hline & \multirow[t]{2}{*}{ Recession } & COGS & $1 \%$ & $1.03 *$ & $1 \%$ & & 750 & $88.20 *$ \\
\hline & & $\mathrm{OC}$ & $1 \%$ & $0.95^{*}$ & $1 \%$ & $0.80 *$ & 750 & $88.23 *$ \\
\hline \multirow{6}{*}{ Russia } & $2004 / 2008$ & SG\&A & $1 \%$ & & $1 \%$ & \multirow{6}{*}{$2.87 *$} & 95 & $0.82 *$ \\
\hline & Prosperity & COGS & $1 \%$ & $2.03 *$ & $1 \%$ & & 95 & $64.76^{*}$ \\
\hline & & OC & $1 \%$ & $0.71 *$ & $1 \%$ & & 95 & $51.71 *$ \\
\hline & $2009 / 2013$ & SG\&A & $1 \%$ & $0.83^{*}$ & $1 \%$ & & 95 & $30.68 *$ \\
\hline & Recession & COGS & $1 \%$ & $1.62 *$ & $1 \%$ & & 95 & $78.18 *$ \\
\hline & & $\mathrm{OC}$ & $1 \%$ & $0.77 *$ & $1 \%$ & & 95 & $85.68 *$ \\
\hline
\end{tabular}

* Significance at $5 \%$

Source: Research data.

As shown in Table 3, in South Africa the asymmetric behavior of costs in the period of prosperity was checked only for the cost of goods sold, which increased sales by $1 \%$ causes an increase in cost of goods sold at $0.96 \%$, and the decrease in sales in the same proportion causes a decrease in cost of goods sold at $1.27 \%$, rejecting the $\mathrm{H} 2$ hypothesis of this research.

In the recession period, the behavior of costs has shown asymmetric and sticky to the cost of goods sold and operating costs, which increased sales by $1 \%$ causes an increase in cost of goods sold of $1.07 \%$ and operating costs of $1.04 \%$. On the other hand, the reduction in sales by $1 \%$ causes a decrease in cost of products sold at $0.61 \%$ and the operating costs of $0.60 \%$, rejecting the hypothesis $\mathrm{H} 3$. 
By comparing the behavior of selling, general and administrative between the period of prosperity and economic recession, it appears that this increases by $0.91 \%$ in the period of economic prosperity, but increase in a lower proportion $(0.74 \%)$ in periods of recession, which is consistent with the hypothesis H4. This implies that managers excel in hiring new resources in good times, but are hesitant to hire extra resources during periods of economic recession.

On the other hand, when comparing the behavior of cost of goods sold between the period of prosperity and economic recession, the results indicate that an increase of $1 \%$ in sales leads to an increase of $0.96 \%$ in periods of prosperity, and increases in higher proportion $(1.07 \%)$ during periods of economic recession. Given this result, leans to reject the hypothesis $\mathrm{H} 4$ from this model, indicating that managers have proactively forward reaction to economic diversity, where there is a preference in hiring new resources in periods of recession and accommodation in periods of prosperity.

This fact can be explained by the intention to increase resources in order to counter and face the negative aspects of economic crisis. Moreover, it was found that when there is a decrease of $1 \%$ in sales, cost of goods sold in times of prosperity reduces by $1.27 \%$. On the other hand, in periods of recession the reduction is $0.61 \%$. Such evidence suggests the rejection of the fifth research hypothesis (H5). The explanation for this evidence is that in times of recession governments creates incentives for organizations to maintain some features, such as maintaining jobs, for example. As far back as good times, there may be an accommodation front management to tackle the existing markets.

Regarding the comparison of the behavior of operating costs in South Africa, between periods of prosperity and recession, it was observed that the increase of $1 \%$ in sales leads to increase of $0.96 \%$ in operating costs during periods of economic prosperity. However, in the period of recession, the increase was $1.04 \%$. These results suggest the rejection of the fourth research hypothesis $(\mathrm{H} 4)$ for this country.

In Brazil, the behavior of costs in the period of prosperity is symmetrical, rejecting the possibility of inference of the hypothesis H2. On the other hand, in the period of economic recession, it is observed that there was asymmetry of costs for all models tested (SG\&A; COGS, OC), and in all cases the costs were sticky, rejecting the hypothesis H3. Therefore, in Brazil, it can be seen that all costs formats are sticky in times of economic recession, which shows the difficulty faced by these organizations on its cost structure, to reduce their costs in downturns economic, a fact that makes these companies are affected before the organizational competitiveness.

When comparing the asymmetric behavior of costs between the period of prosperity and economic recession, it was verified that the selling, general and administrative, on increased sales by $1 \%$, had its increased prosperity at $0.99 \%$, and in period of recession in $0.81 \%$, which accepts the hypothesis $\mathrm{H} 4$ for this model. On the other hand, the cost of goods sold, increases of $1 \%$ of sales, increased by $1.01 \%$ in the period of prosperity, and its increase in the recession period is $1.29 \%$, rejecting the hypothesis H4 for this model. Similarly, operating costs with an increase of $1 \%$ in sales increase by $1.03 \%$ in the period of prosperity and $1.03 \%$ in the period of recession. Thus, also rejects the $\mathrm{H} 4$ hypothesis for this model.

In China the behavior of operating costs in period of prosperity proved to be asymmetric and sticky, accepting the hypothesis $\mathrm{H} 2$, that the increase in operating costs is higher than the decrease. In the recession, it was observed that the selling, general and administrative and operating costs shown to be asymmetric and sticky, however, the hypothesis H3 was rejected, 
since the reduction in operating costs was lower than the increase in comparison to the same proportion of the variation in revenues from sales.

Regarding the increase in costs in the period of prosperity compared to the period of recession, it was observed that the selling, general and administrative, increased by $0.70 \%$, with increased sales by $1 \%$, and in period of recession the increase was $0.50 \%$ for a $1 \%$ increase in revenue from sales. These results allow the acceptance of the hypothesis H4. On the other hand, in relation to costs of goods sold and operating costs, it was verified that in period of recession from an increase in sales of $1 \%$, there is an increase in the cost of $1.03 \%$ and $0.95 \%$ respectively. In the prosperity, the increase is $1.02 \%$ and $0.95 \%$, respectively, thereby rejecting up hypothesis $\mathrm{H} 4$ for these models. Finally, China, it was found that the decrease in the $1 \%$ revenue period of prosperity generates a decrease in operating costs to $0.85 \%$. However, at the decrease in the recession period is $0.80 \%$, accepting the hypothesis H5 for the model.

Regarding Russia, it was found that the behavior of costs in the period of prosperity is symmetrical, rejecting the hypothesis $\mathrm{H} 2$. The increase in sales revenue by $1 \%$ provides an increase in cost of goods sold in $1.62 \%$ in recessionary periods. In contrast, the decrease in sales revenue in the same proportion causes a decrease in cost of goods sold of $2.87 \%$.

By comparing the behavior of costs between periods of prosperity and recession, it is observed that the increase in sales revenue by $1 \%$, generates higher costs of goods sold in greater proportion in prosperity $(2.03 \%)$ than in the recession (1.62), accepting hypothesis H4. On the other hand, the opposite occurs with the operating costs in which an increase in sales revenue by $1 \%$, leads to increased operating costs in a greater proportion at the period of recession (0.77) than in prosperity (0.71), rejecting the hypothesis $\mathrm{H} 4$ for this model.

\section{Robustness test}

In the last stage of the research, the robustness test to evaluate the effects of economic growth on the behavior of costs was made, as determined in the research methodology. Therefore, initially identified the two periods of higher and lower PIB in periods of prosperity and recession. This procedure converges to the criteria established by Ibrahim (2015) to perform such a test.

PIB was determined by current prices in US dollars (US). Therefore, in South Africa in the economic prosperity period, the highest rates of PIB occurred in 2006 with \$ 5,604, and in 2007 with $\$ 5,548$. On the other hand, at the period of recession, the lowest PIB rates occurred in 2009, with $\$-1,526$ and 2013, with $\$ 1,891$. In Brazil, at the period of prosperity the highest PIB rates were identified in 2004, with $\$ 5,714$ and in 2007 with $\$ 6,096$. In the period of recession, the lowest rates of PIB was in 2009, with $\$-0,328$, and in 2012 with $\$ 1,032$. In China, during economic prosperity, the periods which the highest PIB was a peak was in 2006, with $\$ 12,677$, and in 2007 with $\$ 14,200$. However, the worst rates in the recession occurred in 2012 , with $\$ 7,652$, and in 2013 , with $\$ 7,700$. Regarding Russia, the economic prosperity the best PIB rates were noted in 2006 with $\$ 8,153$, and in 2007 with $\$ 8,535$. In contrast, the worst rates in the period of recession were identified in 2009 , with $\$-7,800$, and in 2013 with $\$ 1,300$.

Table 4 presents the results of the robustness test of the asymmetric behavior of costs in periods of greater prosperity and economic recession. 
Table 4

Robustness Test asymmetrical behavior of costs in periods of prosperity and recession

\begin{tabular}{|c|c|c|c|c|c|c|c|c|}
\hline \multirow{2}{*}{ Country } & \multirow{2}{*}{ Period } & \multirow{2}{*}{ Model } & \multicolumn{2}{|c|}{ Increase } & \multicolumn{2}{|c|}{ Decrease } & \multirow{2}{*}{ Obs. } & \multirow{2}{*}{$\mathrm{R}^{2}$} \\
\hline & & & Scenario & $\beta_{1}$ & Scenario & $\beta_{1+} \beta_{2}$ & & \\
\hline \multirow{6}{*}{ South Africa } & 2006 e 2007 & SG\&A & $1 \%$ & & $1 \%$ & & 50 & $3.85 *$ \\
\hline & Prosperity & COGS & $1 \%$ & $0.97 *$ & $1 \%$ & & 50 & $0.95^{*}$ \\
\hline & & OC & $1 \%$ & $0.97 *$ & $1 \%$ & & 50 & $0.96 *$ \\
\hline & 2009 e 2013 & SG\&A & $1 \%$ & & $1 \%$ & & 50 & $11.42 *$ \\
\hline & Recession & COGS & $1 \%$ & $1.02 *$ & $1 \%$ & $0.65^{*}$ & 50 & $0.82 *$ \\
\hline & & OC & $1 \%$ & $1.03 *$ & $1 \%$ & $0.60 *$ & 50 & $0.88 *$ \\
\hline \multirow{6}{*}{ Brazil } & 2004 e 2007 & SG\&A & $1 \%$ & $1.08 *$ & $1 \%$ & & 132 & $27.05^{*}$ \\
\hline & Prosperity & COGS & $1 \%$ & $1.06 *$ & $1 \%$ & & 132 & $29.83 *$ \\
\hline & & OC & $1 \%$ & $1.03 *$ & $1 \%$ & & 132 & $93.66^{*}$ \\
\hline & 2009 e 2012 & SG\&A & $1 \%$ & $0.76^{*}$ & $1 \%$ & $0.04 *$ & 132 & $40.46^{*}$ \\
\hline & Recession & COGS & $1 \%$ & $1.21 *$ & $1 \%$ & $0.11^{*}$ & 132 & $87.25^{*}$ \\
\hline & & $\mathrm{OC}$ & $1 \%$ & $1.07 *$ & $1 \%$ & $0.11 *$ & 132 & $82.77 *$ \\
\hline \multirow{6}{*}{ China } & 2006 e 2007 & SG\&A & $1 \%$ & $0.99 *$ & $1 \%$ & & 300 & $91.42 *$ \\
\hline & Prosperity & COGS & $1 \%$ & $1.06^{*}$ & $1 \%$ & & 300 & $73.95 *$ \\
\hline & & $\mathrm{OC}$ & $1 \%$ & $0.62 *$ & $1 \%$ & & 300 & $16.01 *$ \\
\hline & 2012 e 2013 & SG\&A & $1 \%$ & $0.99 *$ & $1 \%$ & & 300 & $86.01 *$ \\
\hline & Recession & COGS & $1 \%$ & $0.65^{*}$ & $1 \%$ & $0.11 *$ & 300 & $19.68 *$ \\
\hline & & $\mathrm{OC}$ & $1 \%$ & $0.93 *$ & $1 \%$ & & 300 & $91.29 *$ \\
\hline \multirow{6}{*}{ Russia } & 2006 e 2007 & SG\&A & $1 \%$ & & $1 \%$ & & 38 & $6.04 *$ \\
\hline & Prosperity & COGS & $1 \%$ & $4.23^{*}$ & $1 \%$ & $1.19 *$ & 38 & $50.43 *$ \\
\hline & & OC & $1 \%$ & $1.23^{*}$ & $1 \%$ & & 38 & $41.15^{*}$ \\
\hline & 2009 e 2013 & SG\&A & $1 \%$ & $1.07 *$ & $1 \%$ & & 38 & $26.49 *$ \\
\hline & Recession & COGS & $1 \%$ & $1.49 *$ & $1 \%$ & & 38 & $56.03 *$ \\
\hline & & $\mathrm{OC}$ & $1 \%$ & $0.81^{*}$ & $1 \%$ & & 38 & $85.70 *$ \\
\hline
\end{tabular}

* Significance at $5 \%$

Source: Research data.

In South Africa, in times of greater prosperity the cost are not presented asymmetrically. However, in periods of greater recession, there was asymmetric behavior of cost of goods sold and operating expenses, which, in both cases, presented results that allow the rejection of the hypothesis $\mathrm{H} 3$. In this case, the reduction of the costs is less than its increase, demonstrating the presence of sticky costs.

From the comparison of the behavior of costs between periods of greater prosperity and greater economic recession is possible to infer that with the increase in sales of $1 \%$ in the period of prosperity, there is an increase in cost of $0.97 \%$ and the recession, increase would be $1.02 \%$. Thus, with increased sales, costs tend to increase in greater proportion in the period of recession compared to economic prosperity, rejecting the hypothesis $\mathrm{H} 4$.

In Brazil, it was also not observed asymmetric behavior of costs in periods of greater economic prosperity. On the other hand, during periods of peak recession was observed asymmetric behavior of costs in relation to selling, general and administrative, cost of goods sold and operating expenses. In all cases analyzed, the costs have proved sticky, allowing reject hypothesis $\mathrm{H} 3$, which inferred about the biggest reduction in costs in periods of economic recession.

The comparison behavior of costs between the periods analyzed, it was verified that in selling, general and administrative increased sales by $1 \%$ causes a higher proportion of increase in costs in the period of prosperity. It is possible to accept the hypothesis $\mathrm{H} 4$ research. On the other hand, controversial results were found with respect to cost of goods sold and operating expenses, which increased sales by $1 \%$ causes implies greater proportion of increase in costs 
at the economic period of recession. These results suggest the rejection of the hypothesis H4.

Regarding China, it was observed only the asymmetric behavior of costs at the economic period of recession. In this case, the asymmetric behavior is in relation to costs of goods sold, where the costs were identified as sticky as the increased revenues by $1 \%$ leads to an increase in $0.65 \%$ in costs, and decreased revenue in $1 \%$ causes a decrease in costs just $0.11 \%$. These results allow for the rejection of the hypothesis $\mathrm{H} 3$.

Comparing the periods analyzed, the results indicate that with the increase in sales of $1 \%$ there is an increase in cost of goods sold in $1.06 \%$ in the period of prosperity. On the other hand, the same increase in sales in the economic period of recession causes an increase in cost of goods sold of $0.65 \%$. Therefore, may be accepted hypothesis $\mathrm{H} 4$ for this model. In contrast, regarding the operating expenses that happens is the reverse, having a higher increase in operating expenses at the economic period of recession. Therefore reject the hypothesis $\mathrm{H} 4$ for this model.

Finally, in Russia, in times of greater economic prosperity, sticky cost behavior was observed in costs of goods sold, which increased sales by $1 \%$ leads to an increase in costs in $4.23 \%$ and the decrease in sales in $1 \%$ causes a decrease in costs by $1.19 \%$. These results suggest the acceptance of the hypothesis $\mathrm{H} 2$ of this research.

Comparing the observed periods, it was found that the cost of goods sold and operating expenses in the greater economic prosperity period had increased costs in greater proportion compared to the decrease in costs, which also allows you to accept in both cases the H4 hypothesis of the research.

\section{Results of hypothesis testing}

Table 5 presents a summary of the test results of the first research hypothesis: H1 - Costs responds asymmetrically to a change in equivalent sales revenue in the companies belonging to the BRICS countries.

Table 5

Summary of findings related hypothesis 1

\begin{tabular}{|c|c|c|c|c|c|c|c|}
\hline \multirow[b]{2}{*}{ Country } & \multirow[b]{2}{*}{ Costs } & \multicolumn{6}{|c|}{$H_{1}$} \\
\hline & & $\begin{array}{l}\text { General } \\
\text { Period }\end{array}$ & Prosperity & Recession & scenario & $\begin{array}{l}\text { Prosperity } \\
\text { Robustness }\end{array}$ & $\begin{array}{c}\text { Recession } \\
\text { Robustness }\end{array}$ \\
\hline \multirow[t]{3}{*}{ South Africa } & SG\&A & $\mathrm{R}$ & $\mathrm{R}$ & $\mathrm{R}$ & $1 \%$ & $\mathrm{R}$ & $\mathrm{R}$ \\
\hline & COGS & $\mathrm{R}$ & A & A & $1 \%$ & A & A \\
\hline & $\mathrm{OC}$ & A & $\mathrm{R}$ & A & $1 \%$ & A & A \\
\hline \multirow[t]{3}{*}{ Brazil } & SG\&A & A & $\mathrm{R}$ & A & $1 \%$ & $\mathrm{R}$ & $\mathrm{A}$ \\
\hline & COGS & $\mathrm{A}$ & $\mathrm{R}$ & A & $1 \%$ & $\mathrm{R}$ & A \\
\hline & $\mathrm{OC}$ & A & $\mathrm{R}$ & A & $1 \%$ & $\mathrm{R}$ & A \\
\hline \multirow[t]{3}{*}{ China } & SG\&A & $\mathrm{A}$ & $\mathrm{R}$ & $\mathrm{A}$ & $1 \%$ & $\mathrm{R}$ & $\mathrm{R}$ \\
\hline & COGS & $\mathrm{R}$ & $\mathrm{R}$ & $\mathrm{R}$ & $1 \%$ & $\mathrm{R}$ & A \\
\hline & $\mathrm{OC}$ & A & A & A & $1 \%$ & $\mathrm{R}$ & $\mathrm{R}$ \\
\hline \multirow[t]{3}{*}{ Russia } & SG\&A & $\mathrm{R}$ & $\mathrm{R}$ & $\mathrm{R}$ & $1 \%$ & $\mathrm{R}$ & $\mathrm{R}$ \\
\hline & COGS & $\mathrm{A}$ & $\mathrm{R}$ & A & $1 \%$ & A & $\mathrm{R}$ \\
\hline & $\mathrm{OC}$ & $\mathrm{R}$ & $\mathrm{R}$ & $\mathrm{R}$ & $1 \%$ & $\mathrm{R}$ & $\mathrm{R}$ \\
\hline
\end{tabular}

R: Hypothesis Rejected; A: Hypothesis accepted.

Source: Research data. 
In general, it appears that in South Africa selling, general and administrative results showed that the behavior of these costs is symmetrical in all tests. Regarding the cost of sales, it appears that the overall analysis, observing the whole period (2004-2013), the behavior of costs shows no asymmetry. However, from the individual analysis of periods of prosperity and recession, it is clear that there is asymmetry in the behavior of costs. These results are reinforced by the analysis of robustness tests, which show that in periods of greater economic prosperity there is asymmetry in the behavior of costs. The same is observed in relation to the measurement model of the total costs, which shows that there robustness with certain asymmetric behavior.

These results differ in part from those found in Brazil. In this country, the evidence found from the tests indicate that the selling, general and administrative, costs of goods sold and operating costs are symmetrical in all periods of prosperity. However, they are asymmetric when the overall period analysis and in recessionary periods. These results are confirmed in robustness tests performed in this study, reinforcing such evidence.

Regarding China, the results are heterogeneous, differ significantly from previous findings. This case, the behavior of costs is asymmetric in the overall review period for general and administrative expenses with sales, and operating costs. In periods of prosperity and recession, the behavior of operating costs was also asymmetrical. These results were not confirmed in robustness test. Thus, given the high variability in the results found in the various tests performed, one can not infer conclusively about the behavior of costs in this country.

The results found in the sample of Russian companies provide confirmatory evidence that the selling, general and administrative and operating costs are symmetric for all tests in all investigated periods. On the other hand, in relation to costs of goods sold, the results indicated at the total period, asymmetric behavior even identified behavior in times of recession. However, the results of robustness test of these findings differ. So it was not possible to make a conclusive and generalized inferences about the results in Russian companies.

Analyzing comparatively the results found in this research stage, it appears that the behavior of selling, general and administrative is similar between South Africa and Russia, and between these countries and Brazil (only in economic prosperity period), being symmetric in all these cases. In turn, the behavior of the cost of goods sold is compatible between South Africa and Brazil in the period of economic recession, and asymmetrical in these cases. Regarding the behavior of the operating costs, it is observed that these are compatible between South Africa and Brazil in times of economic recession, also being asymmetric these periods. In other observations, the results were partially divergent.

Given the above, in relation to the asymmetric behavior of costs on a cross-countries perspective in emerging countries of the BRICS (Brazil, Russia, South Africa and China), it can infer that South Africa and Brazil have behavior costs of certain proximity, however unlike the behavior observed in China and Russia companies. Thus, the evidence found in this study converge to the findings identified in the study by Banker et al., (2014) indicating that the cost asymmetry level can vary systematically between the cost accounts, business, different industries and countries. Table 6 shows a summary of the results found for the other hypotheses tested in this research. 
Table 6

Summary of findings related hypotheses 2, 3, 4 and 5

\begin{tabular}{lccccccccc}
\hline \multirow{2}{*}{ Country } & & \multicolumn{1}{c}{$H_{1}$} \\
\cline { 3 - 9 } & Costs & Norm. & Rob. & Norm. & Rob. & Norm. & Rob. & Norm. & Rob. \\
\hline South Africa & SG\&A & - & - & - & - & $\mathrm{A}$ & - & - & - \\
& COGS & $\mathrm{R}$ & - & $\mathrm{R}$ & $\mathrm{R}$ & $\mathrm{R}$ & $\mathrm{R}$ & $\mathrm{R}$ & - \\
& OC & - & - & $\mathrm{R}$ & $\mathrm{R}$ & $\mathrm{R}$ & $\mathrm{R}$ & - & - \\
\hline Brazil & SG\&A & $\mathrm{R}$ & - & $\mathrm{R}$ & $\mathrm{R}$ & $\mathrm{A}$ & $\mathrm{A}$ & - & - \\
& COGS & $\mathrm{R}$ & - & $\mathrm{R}$ & $\mathrm{R}$ & $\mathrm{R}$ & $\mathrm{R}$ & - & - \\
& OC & $\mathrm{R}$ & - & $\mathrm{R}$ & $\mathrm{R}$ & $\mathrm{R}$ & $\mathrm{R}$ & - & - \\
\hline China & SG\&A & - & - & $\mathrm{R}$ & - & $\mathrm{A}$ & $\mathrm{R}$ & - & - \\
& COGS & - & - & - & $\mathrm{R}$ & $\mathrm{R}$ & $\mathrm{A}$ & - & - \\
& OC & $\mathrm{A}$ & - & $\mathrm{R}$ & - & $\mathrm{R}$ & - & $\mathrm{A}$ & - \\
\hline Russia & SG\&A & - & - & - & - & - & - & - & - \\
& COGS & $\mathrm{R}$ & $\mathrm{A}$ & - & - & $\mathrm{A}$ & $\mathrm{A}$ & - & - \\
& OC & - & - & - & - & $\mathrm{R}$ & $\mathrm{A}$ & - & - \\
\hline
\end{tabular}

Norm .: Test shown in Table 3 to set asymmetric behavior of costs in periods of prosperity and recession; Rob .: Test presented in Table 4 which defined the robustness of the asymmetric behavior of costs in periods of greater prosperity and greater economic recession; R: Hypothesis Rejected; A: Hypothesis accepted.

Source: Research data.

The second hypothesis developed for this study states: H2 - In times of economic prosperity, the cost increase is higher than in a decrease in response to $1 \%$ change in demand, ie they have asymmetry in costs. This research hypothesis allow for confirmation in just two models analyzed. Thus, considering only the economic prosperity period (2004-2008) established for this investigation, the behavior of the operating costs (OC) was asymmetrical only in China. In the same period this research hypothesis was rejected in all models investigated in Brazil and the model of costs of goods sold (COGS) in South Africa and Russia.

In robustness test considering the two periods of better PIB, in Russia the behavior of cost of goods sold (COGS) was also asymmetrical. However, the results for the remaining robustness tests conducted to test this hypothesis research did not reach statistical significance, rejecting it, therefore, the asymmetric behavior of costs in periods of greater prosperity.

Regarding the third research hypothesis, which investigates whether: H3 - During periods of economic recession and financial crisis, the decrease in costs is higher than its increase in response to $1 \%$ change in demand, ie they do not have asymmetry in costs, the results did not indicate asymmetric behavior in any focus country. These results show that the periods of greatest economic recession, the companies surveyed do not tend to have sticky cost behavior.

The fourth research hypothesis states that: $\mathrm{H} 4$ - If demand increases by $1 \%$, the costs will increase in higher proportion in the economic prosperity period than during the economic recession. The findings indicate that the selling, general and administrative (SG\&A) are asymmetrical at the economic period of prosperity for companies in South Africa, Brazil and China, confirming this hypothesis more clearly in Brazil, since the robustness test showed confirmatory results. In addition, it obtained evidence that in Russia, companies showed asymmetry in the cost of goods sold (COGS) in periods of economic prosperity and is also confirmed by the robustness test.

Regarding the fifth research hypothesis, by which investigated: H5 - If demand decreases by $1 \%$, the costs will decrease in higher proportion in the economic recession period than during 
the economic prosperity, the results pointed inferences only operating costs (OC) companies in China, whereas for other relations can not be made conclusive considerations. Thus, it can be concluded that the Chinese companies operating costs decline with greater intensity that the decrease in demand in the period of economic recession, showing effectiveness of such companies to combat the cost and adapt to the macroeconomic environment factors.

It appears that the robustness test confirmed the findings for South Africa on the hypotheses 3 and 4 on the cost of goods sold and operating costs. In Brazil, the findings indicate that the robustness test confirmed the evidence pointed in Hypothesis 3 regarding the selling, general and administrative, cost of goods sold and operating costs. In addition, confirmations were shown to the findings of hypothesis 4 regarding the selling, general and administrative, cost of goods sold and operating costs.

In Russia it was confirmed evidence of the hypothesis 4 with respect to cost of goods sold and operating costs. Contradictory results were found with respect to China in the hypothesis 4 on selling, general and administrative and cost of goods sold. In relation to Russia, it was also found contradictory results regarding the hypothesis 2 , with respect to cost of goods sold.

\section{Conclusions and recommendations}

The results indicate that in South Africa operating costs behave asymmetrically; in Brazil cost behavior is asymmetrical to the selling, general and administrative, the cost of goods sold and operating costs; in China costs selling, general and administrative and operating costs are asymmetric; and finally, in Russia the cost of goods sold are asymmetrical, where for these accepts the hypothesis 1 .

The findings corroborate the evidence of asymmetry in costs exposed by the study Noreen and Soderstrom (1994, 1997); Anderson and Lamen (2007); Balakrishnan and Gruca (2008), Costa et al., (2013), and Balakrishnan et al., (2014). Moreover, it appears that a cost asymmetry of variation between countries, a fact that confirms the study of Anderson et al., (2003); Calleja et al., (2006) and Pamplona et al., (2016) that changes in the behavior of costs depend heavily on the economic environment in which the organizations are located.

Regarding the fact that economic prosperity increased costs is higher than its decrease and have asymmetry, it is concluded that only in China the behavior of operating costs proved to be asymmetric and sticky at the period of prosperity, accepting for this if the hypothesis 2 . Thus, the findings related companies in South Africa, Brazil and Russia contrary to the inferences of Zuijlen studies (2012) and Ibrahim (2015).

A similar result was found in the hypothesis 3 in which it was not proven in any of the BRICS countries during periods of economic recession, the decreased costs is higher than its increase and response to change of $1 \%$ in demand, ie not pointing for presence of asymmetry in costs, contrary to evidence Dierynck et al., (2012); Zuijlen (2012); Balakrishman et al., (2014) and Ibrahim (2015).

Regarding the costs increase in proportion higher than the demand in economic prosperity period, the findings indicate that only Russia pointed probability for such an occurrence, taking in this case the hypothesis 4; and corroborating the inferences of Zuijlen (2012) and Ibrahim (2015). Finally; with respect to decrease costs in proportion bigger than the demand during the period of economic recession; the results confirm the fact only to China, corroborating Zuijlen findings (2012) and Ibrahim (2015). 
In summary, the results indicate that the costs have asymmetric behaviors in certain accounts and also vary in relation to different economic environments related to companies located in the BRICS countries. This evidence support the conclusion that the costs asymmetric behavior occurs differently between BRICS; indicating that the costs of asymmetry level can vary systematically between the cost accounts, business, different industries and countries. It was found that at the economic prosperity period of increased costs is less than its decrease in response to changes in demand in the same proportion. In the period of economic recession to decreased costs is less than its increase.

Although there are differences in a cross-countries perspective, there is evidence that there is asymmetric behavior of costs in companies, generalized way in all countries of the BRICS. In a national perspective; we need to consider a greater need for managers of Brazilian companies with respect to the asymmetric behavior of costs, which found there sticky costs for all studied accounts, a fact that causes concern for the inclusion of organizations on the need to resume economic or maintaining international competitiveness.

The results indicate regarding the effect of economic growth on the behavior of sticky costs; in a generic way in the economic prosperity increased costs is less than its decrease in response to changes in demand in the same proportion. The same is true for the period of economic recession in which generally the decrease in costs is less than its increase in response to changes in demand in the same proportion, if rejecting respectively the hypotheses 2 and 3. Finally, the findings confirm the expectations of Banker et al., (2014) that argue that "[...] we expect the level of asymmetry of the costs to vary systematically in all cost accounts; companies; industries and countries; including the possibility of no viscosity or anti-stiffness"

In general, it contributes to market forecasts by providing evidence that it is necessary to look at the information on cost behavior associated with measurable macroeconomic factors, such as GDP. Moreover, these findings can be compared with other countries because of the differentiation in corporate governance that interferes with the behavior of managers towards cost decisions, as they advocate (Balakrishman et al., 2011, Chen et al., 2012; Banker \& Byzolav, 2014; Richartz, 2016). Finally, the findings showed that even in an economic group with different countries, there is a strong difference in cost asymmetry, and therefore, it can be inferred that such a difference occurs among firms in other countries, a factor that can be explained by other factors, Such as regulation, characteristics of the stock market, corporate governance, manager profile, among others.

The limitation of the study was related to the attribution of differences between countries to a single macroeconomic variable. This factor is limiting since accounting and market regulation can be an explanatory factor for the differences found in countries with similar economies. Therefore, it is recommended that future studies be done, noting only the business environment factors, but it is necessary to include economic sectors that can influence cost behavior through cluster analysis. In addition, the comparison of cost behavior between firms from developed and developing countries may provide interesting findings for observed factors. Finally, the inclusion of market factors, corporate governance, and regulation may help explain the different cost behaviors adopted by managers. 


\section{References}

Abu-Serdaneh, J. (2014). The asymmetrical behavior of cost: evidence from Jordan. International Business Research, 7(8), 113-122. https://doi.org/10.5539/ibr.v7n8p113

Anderson, M.C., Banker, R. D., \& Janakiraman, S. N. (2003). Are selling, general, and administrative costs sticky?. Journal of Accounting Research, 41(1), 47-63. https://doi.org/10.1111/1475-679x.00095

Anderson, S. W., \& Lanen, W. N. (2007). Understanding Cost Management: What Can We Learn from the Evidence on Sticky Costs?. Available at SSRN 975135. https://doi.org/10.2139/ssrn.975135

Balakrishnan, R., \& Gruca, T. S. (2008). Cost Stickiness and Core Competency: A Note. Contemporary Accounting Research, 25(4), 993-1006. https://doi.org/10.1506/car.25.4.2

Balakrishnan, R., Labro, E., \& Soderstrom, N. S. (2014). Cost structure and sticky costs. Journal of Management Accounting Research, 26(2), 91-116. https://doi.org/10.2308/jmar-50831

Banker, R. D., \& Byzalov, D. (2014). Asymmetric cost behavior. Journal of Management Accounting Research, 26(2), 43-79. https://doi.org/10.2139/ssrn.2312779

Banker, R. D., Byzalov, D., Ciftci, M., \& Mashruwala, R. (2014). The moderating effect of prior sales changes on asymmetric cost behavior. Journal of Management Accounting Research, 26(2), 221-242. https://doi.org/10.2139/ ssrn.902546

Banker, R. D., Byzalov, D., \& Plehn-Dujowich, J. M. (2013). Demand uncertainty and cost behavior. The Accounting Review, 89(3), 839-865. https://doi.org/10.2308/accr-50661

Calleja, K., Steliaros, M., \& Thomas, D. C. (2006). A note on cost stickiness: Some international comparisons. Management Accounting Research, 17(2), 127-140. https://doi.org/10.1016/j.mar.2006.02.001

Chen, C. X., Lu, H., \& Sougiannis, T. (2012). The Agency Problem, Corporate Governance, and the Asymmetrical Behavior of Selling, General, and Administrative Costs. Contemporary Accounting Research, 29(1), $252-282$. https://doi.org/10.1111/j.1911-3846.2011.01094.x

Cooper, R., \& Kaplan, R. (1998). The Design of Cost Management Systems: Texts, Cases, and Readings, Prentice Hall, Upper Saddle River, NJ.

Costa, P. S., Marques, A. V. C., Santos, C. K. S., \& Lima, F. D. C. (2013). ,Análise do comportamento assimétrico dos custos nas companhias abertas dos países da América Latina. In: XXX Conferência Interamericana de Contabilidad, Anais... Uruguay: CIC.

Dierynck, B., Landsman, W. R., \& Renders, A. (2012). Do managerial incentives drive cost behavior? Evidence about the role of the zero earnings benchmark for labor cost behavior in private Belgian firms. The Accounting Review, 87(4), 1219-1246. https://doi.org/10.2308/accr-50153

Frezatti, F., De Aguiar, A. B., De Araujo Wanderley, C., \& Malagueño, R. (2015). A Pesquisa em Contabilidade Gerencial no Brasil: Desenvolvimento, Dificuldades e Oportunidades. Revista Universo Contábil, 11(1), 47-68. https://doi.org/10.4270/RUC.2015103

Garrison, R. H., \& Noreen, E. W. (2001). Contabilidade Gerencial. Rio de Janeiro: LTC.

He, D., Teruya, J., \& Shimizu, T. (2010). Sticky selling, general, and administrative cost behavior and its changes in Japan. Global Journal of Business Research, 4(4), 1-10. Disponible en: https://papers.ssrn.com/sol3/papers. cfm?abstract_id=1871276, consultado 10/08/16.

Ibrahim, A. E. A. (2015). Economic growth and cost stickiness: evidence from Egypt. Journal of Financial Reporting and Accounting, 13(1), 119-140. https://doi.org/10.1108/jfra-06-2014-0052

Jensen, M. C., \& Meckling, W. H. (2008). Teoria da firma: comportamento dos administradores, custos de agência e estrutura de propriedade. Revista de Administração de Empresas, 48(2), 87-125. https://doi.org/10.1590/s003475902008000200013

Malcom, R. E. (1991). Overhead control implications of activity costing. Accounting Horizons, 5(4), 69-78. Disponible en: https://search.proquest.com/openview/3faa22f7749e51966298932f39d80f26, consultado: 15/08/16.

Marques, A. V. C., Santos, C. K. S., Lima, F. D. C., \& de Souza Costa, P. (2014). Cost stickiness in Latin American open companies from 1997 to 2012. European Scientific Journal, 10(10), 270-282. Disponible en: http://eujournal. org/index.php/esj/article/view/3284, consultado: 18/08/16. 
Medeiros, O. R. D., Costa, P. D. S., \& Silva, C. A. T. (2005). Testes empíricos sobre o comportamento assimétrico dos custos nas empresas brasileiras. Revista Contabilidade Finanças, 16(38), 47-56. https://doi.org/10.1590/s151970772005000200005

Noreen, E., \& Soderstrom, N. (1994). Are overhead costs strictly proportional to activity?. Journal of accounting and economics, 17(1), 255-278. https://doi.org/10.1016/0165-4101(94)90012-4

Noreen, E., \& Soderstrom, N. (1997). The accuracy of proportional cost models: evidence from hospital service departments. Review of Accounting Studies, 2(1), 89-114. https://doi.org/10.1023/A:1018325711417

Pamplona, E., Fiirst, C., Silva, T. B. J., \& Zonatto, V. C. S. (2016). Sticky costs in cost behavior of the largest companies in Brazil, Chile and Mexico. Contaduría y Administración, 61(4), 682-704. https://doi.org/10.1016/j. cya.2016.06.007

Porporato, M., \& Werbin, E. (2012). Evidence of sticky costs in banks of Argentina, Brazil and Canada. International Journal of Financial Services Management, 5(4), 303-320. https://doi.org/10.1504/ijfsm.2012.048834

Rayburn, G. (1993). Principles of Cost Accounting: Using Cost Management Approach. IRWIN, Burr Ridge, Toronto.

Richartz, F. (2016). Fatores explicativos para o comportamento assimétrico dos custos das empresas brasileiras. 2016. 157 fls. Tese de Doutorado (Doutorado em Ciências Contábeis - Programa de Pós-Graduação em Contabilidade) - Universidade Federal de Santa Catarina - UFSC. Disponible en: https://repositorio.ufsc.br/handle/123456789/172571, consultado: 21/08/16.

Richartz, F., \& Borgert, A. (2014). O comportamento dos custos das empresas brasileiras listadas na BMFBOVESPA entre 1994 e 2011 com ênfase nos sticky costs. Contaduría y Administración, 59(4), 39-70. https://doi.org/10.1016/ s0186-1042(14)70154-8

Richartz, F., Borgert, A., \& Lunkes, R. J. (2014). Comportamento assimétrico dos custos nas empresas brasileiras listadas na BMFBOVESPA. Advances in Scientific and Applied Accounting, 7(3), 339-361. https://doi.org/10.14392/ asaa.2014070302

Scharf, L., Borgert, A., Richartz, F. (2011). Análise estatística dos custos indiretos de produção: uma contribuição ao estudo do custo exato. Revista de Contabilidade e Organizações, 5(12), 135-156. https://doi.org/10.11606/rco. v5i12.34798

Subramaniam, C., \& Weidenmier, M. L. (2003). Additional evidence on the sticky behavior of costs. working paper, Neeley School of Business, TX Christian University, TX, 10 February.

Werbin, E., Marín, L. M. V., \& Porporato, M. (2012). Costos pegajosos (sticky costs) en empresas españolas: un estudio empírico. Contaduría y Administración, 57(2), 185-200. Disponible en: http://www.scielo.org.mx/pdf/cya/ v57n2/v57n2a9.pdf, consultado: 23/08/16.

Yasukata, K. (2011). Are 'Sticky Costs' the Result of Deliberate Decision of Managers?. Available at SSRN 1444746. https://doi.org/10.2139/ssrn.1444746

Yükçü, S., \& Özkaya, H. (2011). Cost behavior in turkish firms: are selling, general and administrative costs and total operating costs" sticky"?. World of Accounting Science, 13(3), 1-28.

Zuijlen, W. V. (2012). Cost behavior in a period of economic crisis and the effect of the frequency of updating information on cost behavior. Master's thesis, Tilburg University, Tilburg, 18 September. 